\title{
Flexural performance of Hybrid Fiber Reinforced Polymer Concrete using PVA fiber
}

\author{
G.Prashanth Naik ${ }^{1}$, K Hemalatha ${ }^{2}$ and Srikanth Konik ${ }^{3}$ \\ ${ }^{1} \mathrm{M}$. Tech Scholar, Gokaraju Rangaraju Institute of Engineering and Technology, Hyderabad, India \\ ${ }^{2}$ Assistant Professor, Gokaraju Rangaraju Institute of Engineering and Technology, Hyderabad, India \\ ${ }^{3}$ Associate Professor, Gokaraju Rangaraju Institute of Engineering and Technology, Hyderabad, India
}

\begin{abstract}
This paper present the experimental result of flexural behavior of Hybrid Fiber Reinforced Polymer (HFRP) concrete beams reinforced with Glass Fiber Reinforced Polymer (GFRP) rebars and steel bars. This experiment is conducted with the aim of replacing steel reinforcement with GFRP rebars to reduce the risk of corrosion of steel in concrete structures. The data presented in this study is obtained by conducting flexural test experiment on four beams of HFRP beams with various PVA fibre dosage of $0 \%$, $0.25 \%$ and $0.5 \%$ and one Pure FRP beam. Fly ash is added by $25 \%$ in the mix as a mineral admixture to control the shrinkage cracks. The test result showed that by addition of PVA fibre in HFRP concrete enhance the mechanical properties of beam like deflections, ductility, load carrying capacity and flexural capacity. The optimum dosage of PVA fibre is $0.25 \%$. which improve flexural strength by $200 \%$ and $31.1 \%$ and ductility increased by $112.2 \%$ and $55.12 \%$ as compared with Pure FRP beam and HFRP beam without PVA fibre.
\end{abstract}

\section{Introduction}

In construction industry use of concrete popularly increases because of its flexibility in preparing, transporting and casting in any shape. Corrosion of steel and brittleness of concrete are the most frequent and important problems in concrete structures. Corrosion of steel is unavoidable and uncontrolled process. Steel may get rust in the process of transporting from industries to the cast in situ and making of skeleton structure of steel even at room temperature. Due to corrosion of steel its volume increased and develop internal pressure in concrete. This pressure develop internal cracks leading to spalling of concrete.To avoid such problems in concrete structures alternative materials are introduced. Glass Fiber reinforced polymer (GFRP) re-bars are one of such materials to overcome these problems by replacing steel in concrete. GFRP rebars offer high resistance to corrosion, high ultimate tensile strength and low unit weight. Thus they exhibits high strength to weight ratio as compared with steel. GFRP rebars are superior to steel, but they posses low ductility and low strain capacity. Ductility of concrete is improved by addition of fibers in concrete. Fiber arrest the propagation cracks and allow multiple crackings, thereby improve the ductility of concrete. Fiber transfer the load across the crack and improve ultimate load carrying capacity of concrete structure.

(Noushini et al 2013) PVA fiber reinforced concrete showed improved mechanical properties, lower flexural stiffness and with higher load carrying capacity.PVA fiber reinforced concrete achieve maximum strength at optimum fiber dosage of $0.25 \%$ and for ultimate deflection and toughness it is showed maximum at $0.5 \%$ of volume of concrete.(M Haskett et al. 2012) Addition of PVA fiber increases the shear strength at low level of fibre content but shear capacity decreases as increasing the fiber content. PVA fibre restrict the crack length resulting small cracks, improve ductility performance by allowing multiple cracks, delay compression failure by restrain concrete from crushing and enhance post cracking tensile strength performance.(xiangjie Raun et al. 2013) Under the application of designed service load GFRP beams develop more deflections and crack width faster than steel reinforced concrete beam, but ultimate flexural capacity of GFRP beam is 91 to $97 \%$ more than that of steel reinforced beam at the same reinforcement ratio. The deflection and crack width observed maximum GFRP beams than those of steel reinforced concrete beams.(Alsayed SH et al. 2000) GFRP rebars have high resistance to corrosion, low unit weight, high tensile strength capacity, non magnetic and also has electric neutrality. So use of GFRP rebars preferred where electromagnetic neutrality required, structure build nearly close to the sea water or in corrosive environment or the structure exposed to deicing agent. 


\section{Experimental program}

\subsection{Materials}

Ordinary Portland cement (OPC) of grade 53 is used in concrete as a binder material. Fly ash also used in the mix to control drying shrinkage and shrinkage cracks. River sand free from silt and dust used as a Fine aggregate. Crushed granite of maximum size $20 \mathrm{~mm}$ used as coarse aggregate. Coarse aggregates blended with $20 \mathrm{~mm}$ and $10 \mathrm{~mm}$ aggregate in equal proportions. Portable grade tap water used for mix preparation and for curing of specimen at room temperature. Polycarboxylic Ether (PCE) based super plasticizer used for improving the workability of concrete mix. PVA fibre of length $6 \mathrm{~mm}$ and aspect ratio 430 used in the mix. The properties of PVA fiber were shown in table 2 . Steel bars of grade $\mathrm{Fe} 550$ and Glass fiber reinforced polymer (GFRP) rebars are used as reinforcement materials.

Table 1. Prop of materials

\begin{tabular}{|l|l|l|}
\hline S.No. & Test & Result \\
\hline & Cement & \\
\hline 1 & Specific gravity & 3.15 \\
\hline 2 & Normal consistency & $31 \%$ \\
\hline 3 & Initial setting time & $35 \mathrm{~min}$ \\
\hline 4 & Fineness test & $7.5 \%$ \\
\hline & Fine aggregate & \\
\hline 5 & Specific gravity & 2.6 \\
\hline & Coarse aggregate & \\
\hline 6 & Specific gravity & 2.62 \\
\hline
\end{tabular}

Table 2. Properties of PVA fibers

\begin{tabular}{|l|l|}
\hline Material & $100 \%$ PVA \\
\hline Specific gravity & 1.29 \\
\hline Formula & $\left(\mathrm{CH}_{2} \mathrm{CHOH}\right) \mathrm{n}$ \\
\hline Fibre type & Bunchy monofilaments \\
\hline Length & $6 \mathrm{~mm}$ \\
\hline
\end{tabular}

Table 3. Properties of steel bar and GFRP rebars

\begin{tabular}{|l|l|l|l|l|}
\hline $\begin{array}{l}\text { Type } \\
\text { of bar }\end{array}$ & Diameter & $\begin{array}{l}\text { Yield } \\
\text { strength }\end{array}$ & $\begin{array}{l}\text { Elastic } \\
\text { modulus }\end{array}$ & $\begin{array}{l}\text { Tensile } \\
\text { strength }\end{array}$ \\
\hline $\begin{array}{l}\text { Steel } \\
\text { bar }\end{array}$ & $12 \mathrm{~mm}$ & $520 \mathrm{MPa}$ & $175 \mathrm{GPa}$ & $670 \mathrm{MPa}$ \\
\hline $\begin{array}{l}\text { GFRP } \\
\text { bar }\end{array}$ & $12 \mathrm{~mm}$ & - & $40 \mathrm{GPa}$ & $820 \mathrm{MPa}$ \\
\hline
\end{tabular}

\subsection{Mixing and specimen preparation}

Mix design is prepared for M30 grade concrete using IS 10262-2009. details of mix proportions are specified in table 4. effect of PVA fibre on strength was not consider in the mix design, it was designed for plane concrete. All mix ingredients are taken and added in the mix by weight.
Mixing of concrete was prepared in a pan mixer. PVA fibers must be added before addition of water in the mix and mix the ingredients for five minutes for uniform distribution of fibre throughout the concrete. The workability of concrete decreases by addition of fibre in it. Polycarboxylic Ether (PCE) based high range water reducer super plasticizer used for obtaining desired workability. The freshly mixed concrete is placed in to the mould of dimensions $150 * 300 * 1500 \mathrm{~mm}$ with reinforcement. All the inner faces of the mould coated with mould oil for easy removal of samples and to prevent sticking of concrete on mould. The compaction of concrete is done by using vibrating machine. Remove the samples from the mould after 24 hours of casting and then place beams in water for curing until test conducted. Total of four rectangular beams were prepared, out of which one was pure FRP beam and other three beams are Hybrid FRP beams with varying in fiber fractions of $0 \%$, $0.25 \%, 0.5 \%$.

Table 4. Concrete mix design specification for M30 grade concrete

\begin{tabular}{|l|l|l|l|l|l|}
\hline Materials & $\begin{array}{l}\text { Ceme } \\
\text { nt }\end{array}$ & $\begin{array}{l}\text { Fly } \\
\text { ash }\end{array}$ & $\begin{array}{l}\text { Fine } \\
\text { aggrega } \\
\text { te }\end{array}$ & $\begin{array}{l}\text { Coarse } \\
\text { aggrega } \\
\text { te }\end{array}$ & $\begin{array}{l}\text { Wate } \\
\text { r }\end{array}$ \\
\hline $\begin{array}{l}\text { Weight }(\mathrm{kg} / \\
\left.\mathrm{m}^{3}\right)\end{array}$ & 306.7 & $\begin{array}{l}76.6 \\
8\end{array}$ & 702.3 & 1301.6 & 132 \\
\hline proportions & 1 & 0.25 & 2.29 & 4.244 & 0.46 \\
\hline
\end{tabular}

\subsection{Reinforcement details}
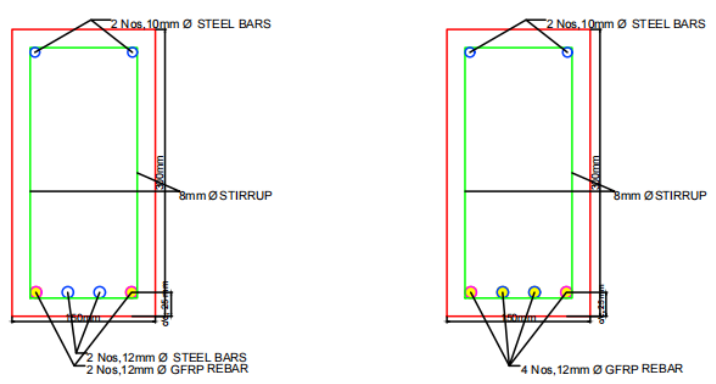

Fig. 1. Cross-section of beams

The tension zone of Pure FRP beam reinforced with 4 no of $12 \mathrm{~mm}$ GFRP re-bars'

Stirrups of $8 \mathrm{~mm}$ diameter steel bars used spacing at 100 $\mathrm{mm}$ at support and $150 \mathrm{~mm}$ at centre.

Top reinforcement of 2 no of $10 \mathrm{~mm}$ diameter steel bars used.

The two bars of GFRP in main reinforcement replaced with steel bars of same diameter for the preparation of Hybrid Fiber Reinforced Polymer (HFRP) beams.

\subsection{Testing method}

Flexural test conducted on rectangular beams of dimensions $150 * 300 * 1500 \mathrm{~mm}$ at the age of 28 days. Test is conducted by mean of four point load bending test. Load is applied at a rate of $1 \mathrm{MPa}$ per minute until the failure of beam. Transverse deflection of the beam 
measured by using linear variable differential transformer (LVDT) at the centre and at the bottom of application of load at a distance of L/3 from support. All the load and deflections are automatically collected and recorded by the sensor instruments. The load and deflections at the appearance of first crack recorded manually.
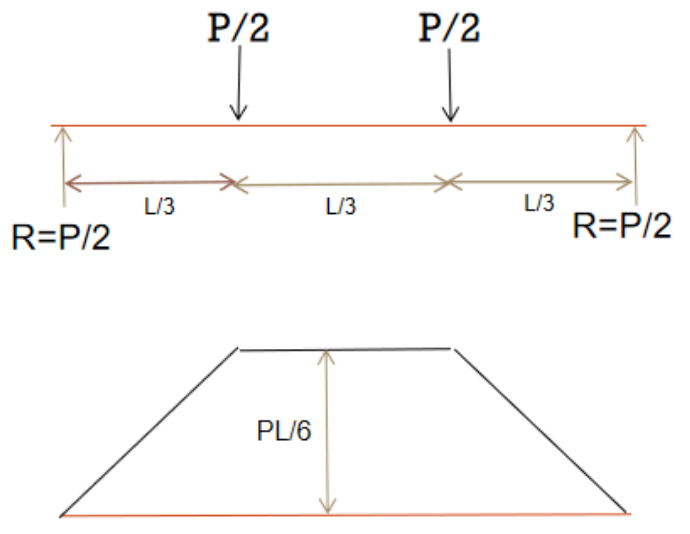

BMD

Fig 2. Loading frame

Flexural strength is calculated by using formula

Reaction at support $=\mathrm{P} / 2$

Bending moment at a distance of $\mathrm{L} / 3=\mathrm{PL} / 6$

Bending strength $\mathrm{f}=\mathrm{M} / \mathrm{Z}=\mathrm{PL} / \mathrm{BD}^{2}$

\section{Result and discussions}

Flexural test conducted on all beams and results are analyzed on the mechanical properties like ductility, ultimate load, ultimate moment of pure FRP and HFRP reinforced concrete beams.

Table 5. Details of beam specifications

\begin{tabular}{|c|c|c|c|c|c|c|c|}
\hline \multirow[t]{2}{*}{ Beam } & \multicolumn{3}{|c|}{$\begin{array}{l}\text { Main } \\
\text { reinforcement bar }\end{array}$} & \multirow{2}{*}{$\begin{array}{l}\mathbf{A f}_{\mathbf{f}} \\
(\mathbf{m} \\
\left.\mathbf{m}^{2}\right)\end{array}$} & \multirow{2}{*}{$\begin{array}{l}A_{\mathbf{s t}} \\
(\mathbf{m} \\
\left.\mathbf{m}^{2}\right)\end{array}$} & \multirow{2}{*}{$\begin{array}{l}\mathbf{f}_{\text {ck }} \\
(\mathbf{N} / \mathbf{m} \\
\left.\mathbf{m}^{2}\right)\end{array}$} & \multirow{2}{*}{$\begin{array}{l}\% P \\
\text { VA }\end{array}$} \\
\hline & $\begin{array}{l}\text { GF } \\
\text { RP }\end{array}$ & $\begin{array}{l}\text { Ste } \\
\text { el }\end{array}$ & $\begin{array}{l}\text { Dia( } \\
\text { mm) }\end{array}$ & & & & \\
\hline $\begin{array}{l}\text { Pure } \\
\text { FRP }\end{array}$ & 4 & - & 12 & 450 & - & 30 & 0 \\
\hline $\begin{array}{l}\text { H0PV } \\
\text { A }\end{array}$ & 2 & 2 & 12 & 227 & 227 & 30 & 0 \\
\hline $\begin{array}{l}\text { H0.25P } \\
\text { VA }\end{array}$ & 2 & 2 & 12 & 227 & 227 & 30 & 0.25 \\
\hline $\begin{array}{l}\text { H0.5P } \\
\text { VA }\end{array}$ & 2 & 2 & 12 & 227 & 227 & 30 & 0.5 \\
\hline
\end{tabular}

Table 6. Flexural characteristics of GFRP reinforced beams

\begin{tabular}{|l|l|l|l|}
\hline Beam & $\begin{array}{l}\text { Ductility } \\
\text { factor }\end{array}$ & $\begin{array}{l}\text { Ultimate } \\
\text { load (KN) }\end{array}$ & $\begin{array}{l}\text { Ultimate } \\
\text { moment } \\
\text { (KN-m) }\end{array}$ \\
\hline Pure FRP & 5.7 & 126 & 31.5 \\
\hline H0PVA & 7.8 & 289 & 72.25 \\
\hline H0.25PVA & 12.1 & 379 & 94.75 \\
\hline H0.5PVA & 8.8 & 257 & 64.25 \\
\hline
\end{tabular}

\subsection{Load- deflection curve of GFRP beams with various PVA fibre fraction}

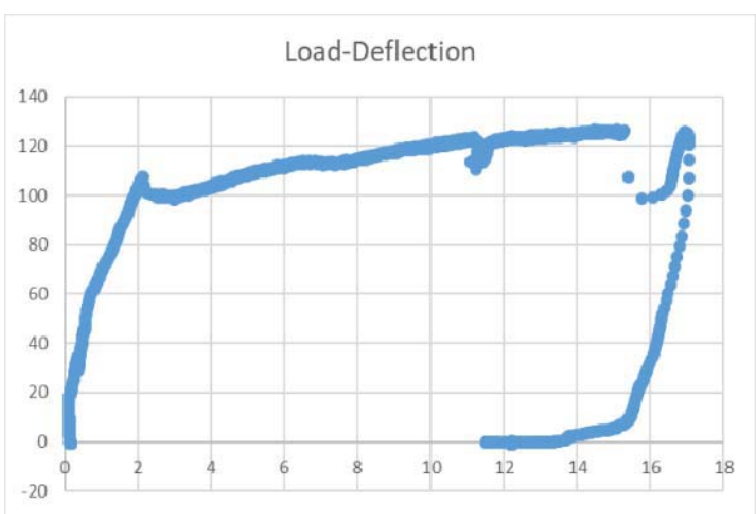

Fig. 3. Load deflection curve of Pure FRP

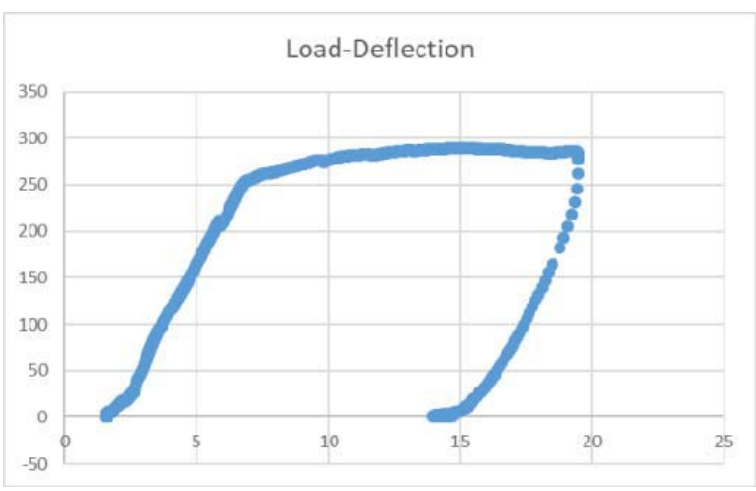

Fig. 4. Load deflection curve of HOPVA

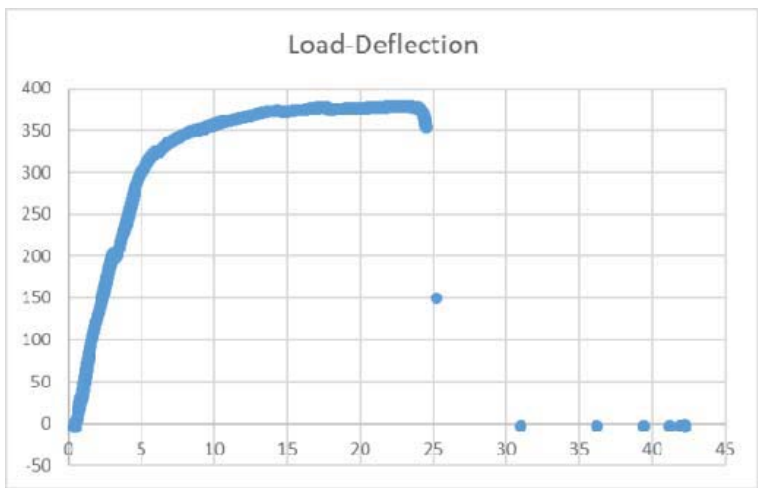

Fig. 5. Load deflection curve of H0.25PVA 


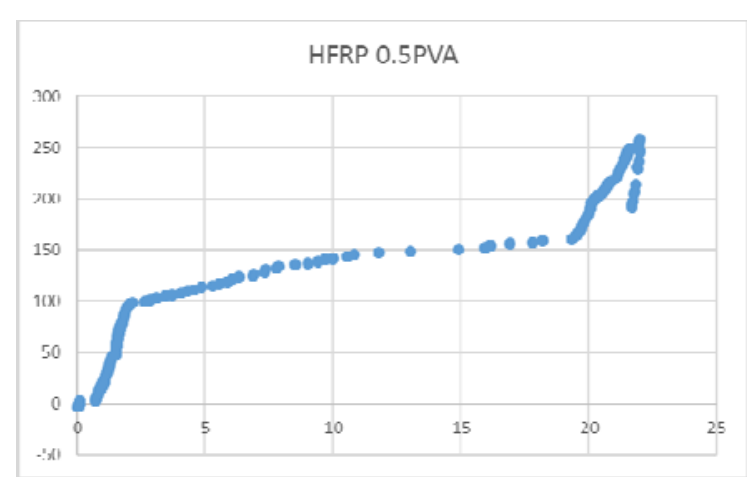

Fig. 6. Load deflection curve of H0.5PVA

The response of load deflection for all beams shown in the above fig. $3,4,5,6$.

The load deflection response curve is initially linear for all the beams up to yield point load or first cracking load. The appearance of first crack delayed with increasing the PVA fibre fraction.

The HFRP beams reinforced with PVA fibre exhibit more deflections and higher load carrying capacity then the beams without PVA fibre.

The beam reinforced with $0.25 \%$ PVA fibre shows maximum ultimate load and deflection. It has $200.7 \%$ more ultimate load as compared with Pure FRP beam.

\subsection{Comparison of variation of Ductility factor}

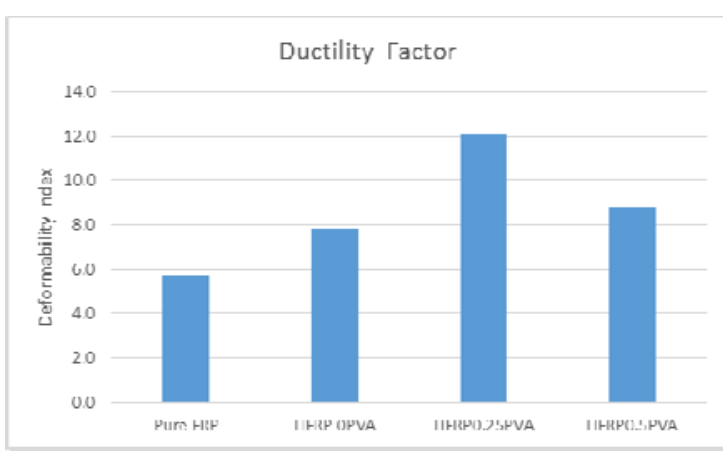

Fig. 7. Variation of ductility factor with PVA fraction

The addition of PVA fibre impart adequate ductility to the HFRP beams.

the beam with addition of PVA fibre will show higher ductility performance as compared with Pure FRP beam and HFRP beam without PVA fibre.

The ductility of beams increases at the lower amount $(0.125 \%)$ of PVA fibre and after that increasing the fibre content will lower the ductility performance.

PVA fibre prevent the crack propagation by transforming load across the cracks and allow multiple cracking, thereby increases the ductility performance of beams.

Ductility performance decreases at higher amount $(0.5 \%)$ of PVA fibre. Due to the presence of higher amount of fibre leads to fiber agglomeration and improper compaction occurs it restrict the ductility performance.

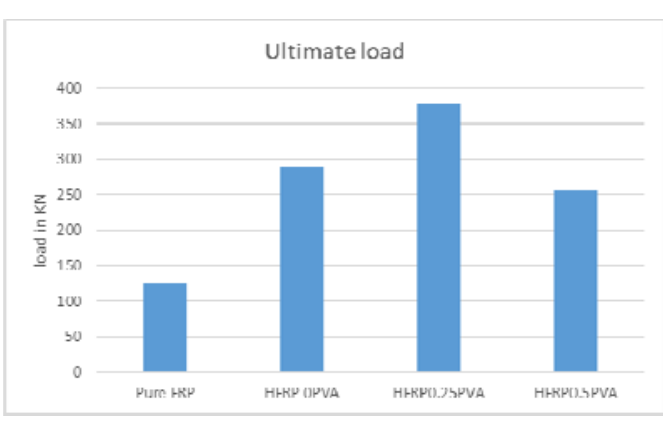

Fig. 8. Variation of load

\subsection{Comparison of flexural strength}

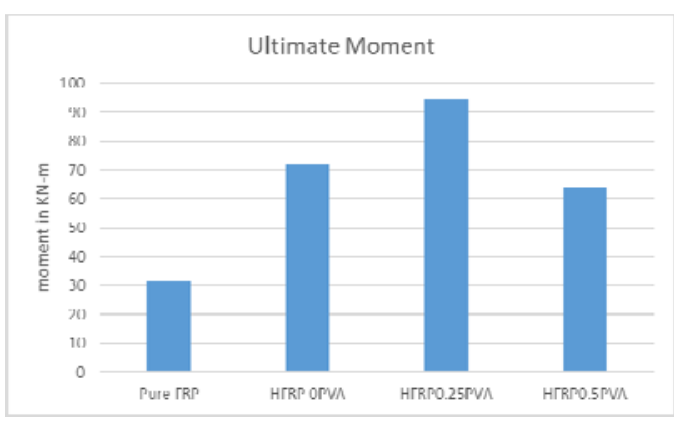

Fig. 9. Variation of ultimate moment

The HFRP beams with PVA fibre shows more ultimate moment then Pure FRP beam.

Lower amount of PVA fibre HFRP beams offer maximum amount of ultimate moment.

Due to the presence of more fibre it will cause negative impact on the flexural strength of the beam. So the HFRP beam with $0.5 \%$ PVA shows lower ultimate moment as compared with HFRP beams without PVA fibre.

\section{Conclusions}

- Addition of PVA fibre to the HFRP beams will perform more ductility and improve load carrying capacity then Pure FRP beam.

- Formation of first crack delayed in PVA fiber reinforced beam then the beam without PVA fibre.

- Optimum dosage of PVA fibre is $0.25 \%$. The beam with $0.25 \%$ PVA fibre shows more ductility, higher ultimate load and higher ultimate moment then all other beams.

- Ultimate load carrying capacity of beams increased by addition of PVA fibre.

- Improvement of ultimate moment by addition of $0.25 \%$ PVA fibre fraction is $198 \%$ and $30.1 \%$ more as compared with Pure FRP and HFRP without PVA fibre.

- Enhancement of ductility factor by addition of $0.25 \%$ PVA fibre is $112.2 \%$ and $55.12 \%$ then Pure FRP and HFRP without PVA fibre. 


\section{References}

1. Noushini, Amin, Kirk Vessalas, and Bijan Samali. (PVA-FRC). (EASEC-13) (2013)

2. Noushini, Amin, Bijan Samali, and Kirk Vessalas. (PVA-FRC). FraMCoS (2013)

3. Zheng, Zhihong, and Dorel Feldman. "Synthetic fibre-reinforced concrete 20.2 185-210 (1995)

4. Noushini, Amin, Bijan Samali, and Kirk Vessalas. Construction and Building Materials 49: 374-383 (2013)

5. Haskett, M., Mohamed Sadakkathulla, M., Oehlers, D., Guest, G., Pritchard, T., Sedev, V., \& Stapleton, B. (2012)

6. Koniki, Srikanth, and D. Ravi Prasad. Construction and Building Materials 207 238-248 (2019)

7. Nataraja, M. C., and Lelin Das. The Indian Concrete Journal 64-70 (2010)

8. IS 456-2000, Concrete Mix Proportioning Guidelines, BIS, New Delhi, India, (2000)

9. IS 10262-2000, Plain and Reinforced Concrete Code of Practice, BIS, New Delhi, India, (2000)

10. IS 9103-1999, Standard Specification for Chemical Admixtures for Concrete, BIS, New Delhi, India, (1999)

11. IS 383-1970 (Reaffirmed 2002), Indian Standard Specification for Coarse and Fine Aggregates from Natural Sources for Concrete, BIS, New Delhi, India, (2002)

12. IS 12269 - 2013, Indian Standard Ordinary Portland cement, 53 Grade - Specification, BIS, New Delhi, India, (2013)

13. Redon, Carl, Victor C. Li, Cynthia Wu, Hideki Hoshiro, Tadashi Saito, and Atsuhisa Ogawa. Journal of materials in civil engineering 13, no. 6 399-406 (2001)

14. Toutanji, Houssam A., and Mohamed Saafi. Structural Journal 97.5 712-719 (2000)

15. Benmokrane, Brahim, et al Journal of Composites for Construction 6.3 143-153 (2002)

16. De Luca, Antonio, Fabio Matta, and Antonio Nanni. ACI structural journal $107.5 \mathbf{5 8 9}$ (2010)

17. Alsayed, S. H., Y. A. Al-Salloum, and T. H. Almusallam. Composites Part B: Engineering 31. 6-7 555-567 (2000)

18. Koniki, Srikanth, et al. Innovative Infrastructure Solutions 6.3 1-14 (2021)

19. Prathipati, SRR Teja, et al. Materials Today: Proceedings 38 2541-2548 (2021)

20. Ramesh, Vemundla, and Koniki Srikanth. E3S Web of Conferences. Vol. 184. EDP Sci. , (2020) 